\title{
Impact of Varietal Replacement Demonstration on the Yield and Economics of Elephant Foot Yam (Amorphophallus paeoniifolius) cv. Gajendra in Bhagalpur District of Bihar
}

\author{
Kamal Kant ${ }^{1}$, Sanjeev Kumar Gupta ${ }^{2}$, S. K. Pathak ${ }^{2}$, Ghanshyam ${ }^{3}$, Amit Kumar ${ }^{4}$, \\ Sanoj Kumar ${ }^{5}$, S. Patil ${ }^{6}$, A. B. Patel ${ }^{2}$ and R.K. Sohane ${ }^{7}$ \\ ${ }^{1}$ Department of Horticulture, ${ }^{2}$ Department of Agronomy, ${ }^{3}$ Department of Soil Science \& \\ Agricultural Chemistry, ${ }^{4}$ Department of Animal Husbandry, ${ }^{5}$ Department of Agricultural \\ Engineering, ${ }^{6}$ Department of Agricultural Extension, \\ ${ }^{7}$ Director Extension Education, Bihar Agricultural University, Sabour, \\ Bhagalpur, Bihar, India
}

\section{Ke ywords \\ Amorphophallus paeoniifolius balanced fertilizers yam farming}

Article Info

Accepted: 08 January 2020 Available Online: 10 February 2020

\section{A B S T R A C T}

Elephant foot yam (Amorphophallus paeoniifolius) is one of the important tuber crops grown for fresh and processing purpose all over the India due to its wider adaptability under various agro-climatic conditions, which plays a major role in supplementing the income of small and marginal farmer of the Bhagalpur district of Bihar state. The present study was carried out at Bhagalpur district during kharif 2017-18 and 2018-19. Varietal replacement through Farmer FIRST Project were conducted on elephant foot yam by the active participation of the farmers with the objective of improved technologies of elephant foot yam production potential. The improved technologies consist improved variety (Gajendra), balanced fertilizers (Soil test based) application and integrated pest and disease management, etc. The development of the agriculture is primarily depends on the application of the scientific technologies by making the best use of available resources. One of the major constraints of traditional elephant foot yam farming is low productivity because of non-adoption of advanced technologies like improved varieties. To increase the production, productivity and quality of agricultural produce, varietal replacement are being conducted at various farmer's field. All the recommended practices were provided to the selected farmers. The data related to the cost of cultivation, production, productivity, gross return and net return were collected as per schedule and analysed. Result of the present study revealed the higher average yield in the varietal replacement demonstration was recorded $(595.5 \mathrm{q} / \mathrm{ha})$ as compared to farmers practice $(288.40 \mathrm{q} / \mathrm{ha})$ traditional adopted by the farmers. The percentage increase in the yield over farmer's 106.48 was recorded. The technology gap and extension gap were computed 159.35 and 307.10 q/ha respectively, along with 48.11 percent of technology index. The varietal replacement demonstration field gave higher average net return Rs. 587630.00 and B:C ratio is 1:5.22. The result of the study indicated the gap existed in the potential yield and demonstration yield is due to soil fertility and weather conditions. Present result clearly show that the yield and economics of elephant foot yam can be boost up by adopting recommended technologies. 


\section{Introduction}

Elephant Foot Yam (Amorphophallus paeoniifolius) is a traditional crop with a long history of cultivation in Asia and the Pacific. It is widely used as a tuber vegetable in India, whereas, it is very closely associated with culture in many of the South Pacific Islands. It ranks fourth after cassava and yam, in terms of total production, area and consumption (Poonia and Pithia 2011).

Elephant foot yam also known as Zimikand or Oel is a tropical tuber crop belong to the monocotyledonous family "Araceae" of the order "Arales" whose members are known as "aroids" (Henry, 2001) and Van Wyk, 2005).

Elephant foot yam is believed to have originated in South Central Asia, perhaps in Eastern India or Malaysia (Sturlevant, 1919). All parts of the plant including corm, cormels, leaves and flowers are edible and contain abundant starch (Bose et al., 2012). Elephant foot yam is a rich source of major components of the diet viz. proteins, minerals and vitamins.

The nutritional value of a food depends upon its nutritional contents, digestibility and the presence or absence of anti-nutrients or toxic factors. Several authors have evaluated the chemical composition of whole corms and cormels of elephant foot yam (Surjit and Tarafdar, 2015).

It has been observed that in spite of the fact that elephant foot yam are neglected crops, their nutritional value is high. Apart from the low fat content, the crop is nutritionally superior to other root and root crops in protein, mineral and vitamin contents (Onwueme, 1978).

Investigation have shown that elephant foot yam contains digestible starch, protein of good quality, vitamin $\mathrm{C}$, thiamine, riboflavin, niacin and high scores of proteins and essential amino acids. The crop is also very rich in dietary fibre, thus, it could be employed in the treatment of diseases such as obesity, diabetes, cancer and gastrointestinal disorders (Mukherjee et al., 2016).

Elephant foot yam is cultivated in an area of around $30 \mathrm{~m}$ ha with an annual production of 774MT (NHB Database, 2018) and the major elephant foot yam growing states are Assam, Bihar, Nagaland, Manipur, Orissa, Maharashtra, Kerala, Andhra Pradesh, Meghalaya, West Bengal, Uttar Pradesh, Gujarat and Tamil Nadu.

In Bihar state total share under elephant foot yam is 4.94 with a production of 36.20 metric tonnes (NHB Database, 2016). Elephant foot yam is mainly grown as a major tuber crop in north Bihar areas like Muzaffarpur, Samastipur, Vaishali, East Chaparan, Madhubani, Shitamarhi, Bhagalpur and Begusarai districts in Bihar.

Despite of the importance of this crop, its cultivation anywhere in India is generally a subsistent to semi-commercial crop due to low productivity because of non-adoption of advanced technologies like improved varieties. To increase the production, productivity and quality of agricultural produce, varietal replacement demonstrations are being conducted at project area various farmers' field.

\section{Materials and Methods}

The varietal replacement demonstration is an applied approach to accelerate the dissemination of proven technologies at project area farmer's fields in a full package and practice mode with an objective to explore the maximum available resources of crop production and also to bridge the 
productivity gaps by enhancing the production in national basket (Choudhary et al., 2018). To overcome the problems faced by the farmers in cultivation of elephant foot yam, integrated crop management in elephant foot yam was conducted by Farmers FIRST Project, Bihar Agricultural University, Sabour, Bhagalpur during Kharif 2017-18 and 2018-19 in five farmers of Bhagalpur district. In the demonstration, improved variety Gajendra was grown in 0.5 ha area each farmer with integrated crop management practices and the farmers practice traditionally in 0.5 ha area for comparison. The integrated crop management practices consisting the conjoint use 20 t/ha FYM with a balanced fertilization of 120:60:80 NPK kg/ha.

Improved variety of elephant foot yam i.e. Gajendra introduced under demonstration was released from a local selection from Kovvur area of Andhra Pradesh is able to yield 50-60 t/ ha. The tubers are non-acrid, well-shaped and generally devoid of cormels or propagules. Treated with fungicide namely, Diathan M-45 and integrated pest management strategies were demonstration as per need.

Selection from local collections of Kovvur, West Godavari district, Average yield of $42.00 \mathrm{t} / \mathrm{ha}$, potential yield Andhra Pradesh, released from Vegetable Research Station, of 55.00 t/ha, matures by 180-210 days Rajendra Nagar, under the aegis of All India CoOrdinated Research Project (AICRP) on Tuber Crops.

The Gajendra variety was a local selection. Salient features of technology are plant height upto $80-90 \mathrm{~cm}$, canopy spread upto $85-92$ $\mathrm{cm}$, pseudostem girth upto $11-15 \mathrm{~cm}$, growth habit is erected, corm type stem, corm size 500 - $700 \mathrm{gm}$ suitable for culinary purpose due softness and non-acrid which make it easy to cook.
Responsive to recommended dose of fertilizer at both rain fed and irrigated conditions situation in Kharif and spring -summer season and field tolerant to pest and leaf blight disease with average yield of 595.50 $\mathrm{q} /$ ha elephant foot yam (Gajendra) may progressively commercialized in Bihar as well as in Jharkhand.

The technological interventions followed in farmers practice and demonstration is given in table 1. Before initiating the demonstration, the beneficiary farmers were given with skill training on various technological interventions to be followed in elephant foot yam cultivation.

The performance of crop was periodically observed by the scientists of Farmers FIRST Project, Bihar Agricultural University, Sabour, Bhagalpur and advisory recommendations were followed. During harvest, yield data was collected from both the demonstration and farmers practice.

At the end, cost of cultivation, net income and cost benefit ratio were worked out. An average of cost of cultivation, yield and net returns of different farmers was analysed by the formula.

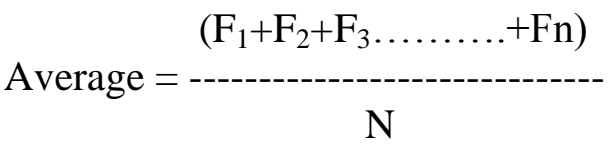

Where,

$\mathrm{F}=$ Farmer $(\mathrm{s})$

$\mathrm{N}=$ No. of farmers

In the present study, technology index was operationally defined as the technical feasibility obtained due to implementation of varietal replacement demonstrations in elephant foot yam. To estimate the technology gap, extension gap and technology index following formula used as given by Samui et al., 2000. 
Technology Gap $=\mathrm{P}_{1}($ Potential yield $)-\mathrm{D}_{1}$ (Demonstration yield)

Extension Gap $=\mathrm{D}_{1}$ (Demonstration yield $)-$ $\mathrm{F}_{1}$ (Farmers yield)

Technology index $=\frac{\text { Potential yield }- \text { Demonstration yield }}{\text { Potential yield }} \times 100$

B: C ratio $=\frac{\text { Net income (Rs/ha) }}{----------}$

Percent increase over farmer's practices

$=$ Improved practices - Farmers practices

Farmers Practices

\section{Results and Discussion}

The economic indices depicted in table 2 showed that the average yield of elephant foot yam variety (Gajendra) were $595.50 \mathrm{q} / \mathrm{ah}$ and 597.40 q/ha during kharif 2017-18 and 201819 respectively under demonstrated technology however, under farmer's practices the average yield were found to be 288.40 $\mathrm{q} / \mathrm{ha}$ and $285.80 \mathrm{q} / \mathrm{ha}$ during respective years. The average percent increases over local yield were 106.48 .

The results clearly indicated the positive effect of varietal replacement demonstration over the existing practices toward enhancing the yield of elephant foot yam in the study area due to use of high yielding variety, timely sowing, balance dose of fertilizers, proper and timely irrigation, need based plant protection etc.

The result is in conformity with the finding of Markam et al., (2019), Tiwari and Saxena (2001) and Tiwari et al., (2003). Yield of the varietal replacement demonstration and potential yield of the crop was compared to estimate the yield gaps which were further categorized into technology and extension gap. The data of table 3 depicted the technology gap in the demonstration yield against potential yield which is $188.92 \mathrm{q} / \mathrm{ah}$ during both the year and reflects the farmer's cooperation in carrying out such demonstrations with encouraging results in subsequent years.

The technology gap observed may be attributing to the dissimilarity in soil fertility status, timely sowing and weather conditions. Similar finding was recorded by Mitra and Samjdar (2010). Further, the higher extension gap was observed. The extension gap ranged from $307.10 \mathrm{q} / \mathrm{ha}$ during the period of study that emphasizes the need to educate the farmers through various means for adoption of improved production technologies to mitigate the extension gap.

The data of table 2 reveals that as far as average economics of elephant foot yam is concerned; gross cost, net income and benefit cost ration were Rs. 1789350.00 /ha, Rs. 1445235.00 /ha and 1:4.23, respectively during 2017-18 and Rs. 1792200.00 /ha, Rs. 1449036 /ha and 1:4.22, respectively during 2018-19 under demonstration plot. However, Rs.869910.00 /ha gross cost, Rs.583958.00 /ha net return with 1:2.07. benefit cost ration during 2017-18 and Rs.874650.00 /ha gross cost, Rs.591302.00 /ha net return with 1: 2.08 Benefit cost ratio observed during 2018-19 under farmer's practice.

The superiority of recommended package of practices under varietal replacement demonstration over farmer's practice was also reported by Mitra and Samajdar (2010) and Balai et al., (2012). From the finding of present study, it can be concluded that use of above prescribed technologies of elephant foot yam cultivation can reduce the technology gap to a considerable extent resulting in to increased productivity as well as quality in Bihar. 
Table.1

\begin{tabular}{|c|c|c|c|c|}
\hline S.No. & $\begin{array}{l}\text { Package of } \\
\text { practices } \\
\text { (Technology } \\
\text { intervention) }\end{array}$ & $\begin{array}{c}\text { Varietal replacement } \\
\text { demonstration } \\
\text { (Recommended package of } \\
\text { practices) }\end{array}$ & $\begin{array}{c}\text { Farmers } \\
\text { practice } \\
\text { (Local/check) }\end{array}$ & Gap \\
\hline 01. & $\begin{array}{l}\text { Selection of } \\
\text { variety }\end{array}$ & Improved variety (Gajendra) & Age old variety & Partial gap \\
\hline 02. & Soil testing & $\begin{array}{l}\text { Have been done in all the } \\
\text { location }\end{array}$ & Not in practice & Full gap \\
\hline 03. & Seed rate & $90 \mathrm{q} / \mathrm{ha}$ & 90 q/ha & Partial gap \\
\hline 04. & Seed treatment & $\begin{array}{l}\text { Seed treated with fungicide } \\
\text { Dithan M-45 }\end{array}$ & Not done & Full gap \\
\hline 05. & Spacing & $70 \mathrm{~cm} \times 60 \mathrm{~cm}$ & $60 \mathrm{~cm} \times 50 \mathrm{~cm}$ & Partial gap \\
\hline 06. & $\begin{array}{l}\text { Application of } \\
\text { recommended } \\
\text { dose of fertilizer }\end{array}$ & $\begin{array}{l}120 \mathrm{~kg} \mathrm{~N}+60 \mathrm{~kg} \mathrm{P}_{2} \mathrm{O}_{5}+80 \mathrm{~kg} \\
\mathrm{~K}_{2} \mathrm{O} \text { per ha }(50 \% \mathrm{~N}+100 \% \mathrm{P} \mathrm{K} \\
\text { at the time of planting and } \\
\text { remaining } 50 \% \mathrm{~N} \text { applied at } 40 \\
\text { days and } 80 \text { days after planting) }\end{array}$ & $\begin{array}{l}\text { Imbalance and } \\
\text { inadequate }\end{array}$ & Partial gap \\
\hline 07. & $\begin{array}{l}\text { Application of } \\
\text { vegetable } \\
\text { special (micro- } \\
\text { nutritional) } \\
\text { Irrigation }\end{array}$ & $\begin{array}{l}\text { Foliar spray of vegetable special } \\
\text { (micro-nutrients) } 75 \mathrm{~g}+15 \text { lit } \\
\text { water }+ \text { lemon }+1 \text { shampoo } \\
\text { (Rs. 1). }\end{array}$ & $\begin{array}{l}\text { Not applied any } \\
\text { micro-nutrient }\end{array}$ & Full gap \\
\hline 08. & Irrigation & $\begin{array}{l}\text { Drip or furrow method of } \\
\text { irrigation at once in a } 7-11 \text { days } \\
\text { interval depend upon soil } \\
\text { condition }\end{array}$ & $\begin{array}{l}\text { Twice in a } \\
\text { month }\end{array}$ & Partial gap \\
\hline 09. & $\begin{array}{l}\text { Weed } \\
\text { management }\end{array}$ & $\begin{array}{l}\text { Pre-emergence } \\
\text { pendimethalin @ } 1.5 \mathrm{~kg} \text { a.i/ha, } \\
\text { followed by hand weeding } \\
\text { depend upon weed intensity. }\end{array}$ & $\begin{array}{l}\text { Weeding is not } \\
\text { common }\end{array}$ & Partial gap \\
\hline 10. & $\begin{array}{l}\text { Plant protection } \\
\text { measures for } \\
\text { control of insect } \\
\text { pest and diseases }\end{array}$ & $\begin{array}{l}\text { Need based application for } \\
\text { control: Aphid and sucking } \\
\text { pest-spraying with diamethoate } \\
\text { ( } 30 \text { EC) } 1.5 \mathrm{ml} / \mathrm{L} \text { of water. Leaf } \\
\text { eating catterpiller: spray NPV } \\
\text { ( } 250 \text { LE/ha). Blight, pyithium } \\
\text { rot \& leaf blight - Spraying of } \\
\text { (COC) blitox } 50- \\
3 \mathrm{~g} / \mathrm{L} \text { of water }\end{array}$ & $\begin{array}{l}\text { Plant protection } \\
\text { is not common }\end{array}$ & Partial gap \\
\hline 11. & Harvesting & Manual & Manual & No gap \\
\hline
\end{tabular}


Table.2 Economics of varietal replacement demonstration of year 2017-18 and 2018-19

\begin{tabular}{|c|c|c|c|c|c|c|c|c|c|c|c|c|c|c|c|}
\hline Variables & & d $(q$ & & & $\begin{array}{l}\text { cost c } \\
\text { tivat } \\
\text { 2s./h }\end{array}$ & & & $\begin{array}{l}\text { Sros } \\
\text { etur } \\
\text { Rs./h }\end{array}$ & & & t ret & & & it ref & \\
\hline 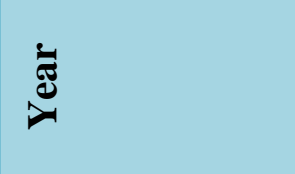 & $\frac{\infty}{\frac{\pi}{\pi}}$ & $\frac{\vec{\alpha}}{\dot{\alpha}}$ & 范 & $\frac{\infty}{\frac{\pi}{n}}$ & 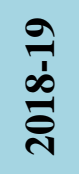 & 总 & $\frac{\infty}{\frac{\pi}{1}}$ & $\frac{0}{\bar{c}}$ & 总 & $\frac{\infty}{\frac{1}{1}}$ & के & 总 & $\frac{\infty}{\frac{1}{5}}$ & के & 密 \\
\hline $\begin{array}{l}\text { Farmers } \\
\text { practice }\end{array}$ & 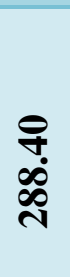 & 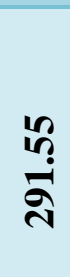 & के. & 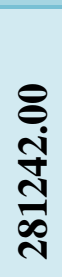 & 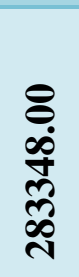 & 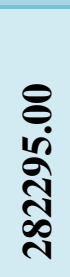 & 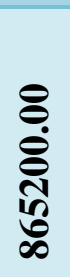 & 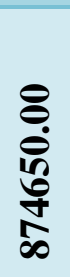 & 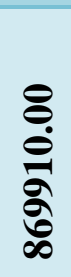 & $\begin{array}{l}8 \\
0 \\
10 \\
10 \\
\text { ஸ̂. } \\
\infty \\
10\end{array}$ & 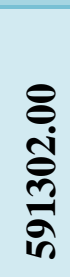 & 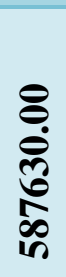 & 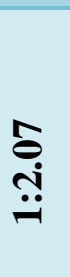 & 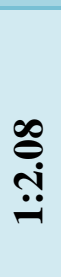 & $\stackrel{\infty}{\stackrel{\infty}{\sim}}$ \\
\hline $\begin{array}{c}\text { Recommended } \\
\text { practices } \\
\text { (Gajendra) }\end{array}$ & $\begin{array}{l}\text { in } \\
\text { in } \\
\text { in }\end{array}$ & 早 & $\begin{array}{l}\text { 10 } \\
\text { की } \\
\text { in }\end{array}$ & 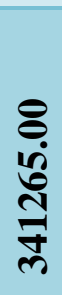 & 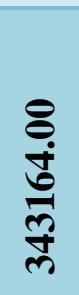 & 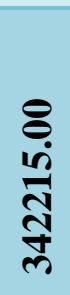 & 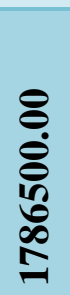 & 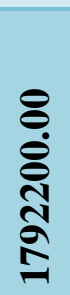 & 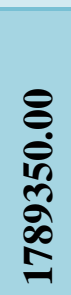 & 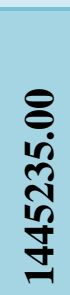 & 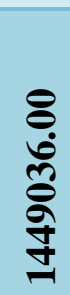 & 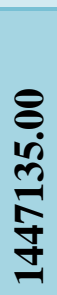 & $\begin{array}{r}\stackrel{\oplus}{+} \\
\stackrel{\leftrightarrow}{\oplus}\end{array}$ & $\begin{array}{l}\underset{\sim}{*} \\
\stackrel{\sim}{*}\end{array}$ & $\begin{array}{l}\tilde{N} \\
\stackrel{+}{*}\end{array}$ \\
\hline
\end{tabular}

Table.3 Yield technology gap and technology index of varietal replacement demonstration

\begin{tabular}{|c|c|c|c|c|c|}
\hline Variables & Yield (q/ha) & $\begin{array}{c}\text { Increase } \\
(\%) \text { over } \\
\text { farmers } \\
\text { Practice }\end{array}$ & $\begin{array}{c}\text { Technology } \\
\text { gap (q/ha) }\end{array}$ & $\begin{array}{c}\text { Extension } \\
\text { gap (q/ha) }\end{array}$ & $\begin{array}{c}\text { Technology } \\
\text { index }(\%)\end{array}$ \\
\hline $\begin{array}{c}\text { Farmers } \\
\text { Practice }\end{array}$ & 289.97 & - & - & - & - \\
\hline $\begin{array}{c}\text { Recommended } \\
\text { practices } \\
\text { (Gajendra) }\end{array}$ & $\mathbf{5 9 6 . 4 5}$ & 106.48 & 159.35 & 307.10 & 48.11 \\
\hline
\end{tabular}

It requires collaborative extension efforts to enhance adoption level of location and crop specific technologies among of the farmers for bridging these gaps. Therefore, extension agencies in the district need to provide proper technical support to the farmers through various educational and extension methods for better elephant foot yam production in
Bhagalpur districts of Bihar.

References

NHB Database, (2016). NHB Database, (2018).

Balai, C.M., Meena, R.P., Meena, B.L. and Bairwa, R.K. (2012). Impact of frontline on rapeseed and mustard yield 
improvement. Indian Res.J.ofExtn Edu., 12(2): 113-116.

Chaudhary, R.P., Choudhary, G.K., Prasad, R., Singh, R. and Chaturvedi, A.K. (2018). Impact assessment of front line demonstration on mustard crop. Int.J.Curr.MicrobiologyApp.Sci.(7): 4737-4742.

Jeengar, K.L., Panwar, P.P. and Pareek, O.P. (2006). Front line demonstration on maize in Bhilwara district of Rajasthan. Current Agric., (30): 115-116.

Mitra, B. and Samajdar, T. (2010). Field gap analysis of rapeseed-mustard through front line demonstration. Agricultural Extension Review, (22): 16-17.

Poonia, T.C. and Pithia, M.S. (2011). Impact of front line demonstrations of chickpea in Gujarat. Legume Research, 34(4): 304-307.

Suryawanshi, S.D. and Prakash, M. (1993). Impact of viable technology of promoting oil seeds in Maharashtra. Indian J. Agri. Econ., 48(420): 102-106.

Samui, S.K., Mitra, S., Roy, D.K., Mondal, A.K. and Saha, D. (2000). Evaluation of front line demonstration on groundnut (Arachis hypogea L.) in Sundarbans. $J$. of Indian Society of Coastal Agri. Res. 18(2): 180-183.

Tiwari, K.B. and Saxena, A. (2001). Economic analysis of FLD of oilseed in Chhindwara.

BhartiyaKrishiAnusandhanPatrika, 16(3\&4): 185-189.

Bose, T.K., Kabir, J. Maity, T.K. Parthasarathy, V.A. and Som, M.G.,
(2003). Vegetable crops, vol 2. NayaUdyog Publishers, Kolkata. Pp: 413-442.

Henry, R.J. (2001). Plant genotyping: The DNA fingerprinting of plants. $C A B$ Publishing, Southern Cross University, Australia.

Sturlevant, E.L., (1919). Note on edible plants. Res. N.Y. Agric. Expt. Stn. 69(70): 185-186.

Onwurme, I.C. (1978). The tropical tuber crops: yams, cassava, sweet potato, cocoyams. John Wiley and Sons, New York.

Surjit, M. and Tarafdar, J. (2015). Diversity in Morpho-Biometrical characters, Nutritional facts and Isozymes activity of Indian landraces of upland Taro (Colocasiaesculanta var. antiquorumL.Scott.)International Journal of Tropical Agriculture, 33(2): 1163-1166.

Mukherjee, D. Roquib, Md. A., Das, N.D. and Mukherjee, S. (2006). A study on genetic variability, character association and path co-efficient analysis on morphological and yield attributing characters of taro (Colocasiaesculanta var. antiquorumL.Scott.). American Journal of Plant Sciences. 7: 479-488.

Markam, S.K., Sahu, B., Thakur, C.L. and Gour, A.R. (2019). Impact of front line demonstrations on the yield and economics of Colocasia (Colocasiaesculanta var. antiquorumL.Scott.) in Kanker District of Chhattisgarh. Int. J. Curr. Microbial. App. Sci. 8(12): 1400-1406.

\section{How to cite this article:}

Kamal Kant, Sanjeev Kumar Gupta, S. K. Pathak, Ghanshyam, Amit Kumar,Sanoj Kumar, S. Patil, A. B. Patel and Sohane. R.K. 2020. Impact of Varietal Replacement Demonstration on the Yield and Economics of Elephant Foot Yam (Amorphophallus paeoniifolius) cv. Gajendra in Bhagalpur District of Bihar. Int.J.Curr.Microbiol.App.Sci. 9(02): 1849-1855. doi: https://doi.org/10.20546/ijcmas.2020.902.211 